\title{
ANALISIS PENDAPATAN PETANI KARET BIBIT UNGGUL DAN BIBIT TRADISIONAL DI KECAMATAN BATANG CENAKU KABUPATEN INDRAGIRI HULU
}

\author{
Iskandar \\ Sekolah Tinggi Ilmu Ekonomi Riau \\ E-mail: iskandar@lecturer.stieriau-akbar.ac.id
}

\begin{abstract}
This research was conducted in the District of Batang Cenaku Indragiri Hulu. This is because the District of Batang Cenaku an area that makes rubber commodity as one commodity and in meeting their needs. The purpose of this study was to determine how the income of farmers in the district rubber rod upstream and Indragiri district Cenaku To know that used descriptive analysis, the data obtained are tabulated and then described by existing theories. The survey results revealed that the rubber plantation is vital to the income of the people in the District of Batang Cenaku Thus it can be seen that the average income of farmers quality seeds rubber plant samples with an area of 1 hectare of $R p$. 8,241,724, - per year, while the average income of farmers' traditional seed samples rubber plant with an area of 2 hectares of Rp. 8,463,739, - per year. A comparison of income between farmers using traditional quality seeds and that happened 2 times where income 1 hectare equals income prefetch queue seeds 2 acres of farmers using traditional seeds. Businesses manage rubber plantation is a tradition for the people of District of Batang Cenaku Indragiri Hulu. Many efforts have been done by the government in the development of rubber plantations, such as by providing quality seeds and adequate capital for rubber farmers.
\end{abstract}

Keywords: Pendapatan, Bibit Unggul, Bibit Tradisional

\section{A. PENDAHULUAN}

Dalam 25 tahun terakhir, subsektor perkebunan karet merupakan salah satu bisnis sttrategis dan andalan dalam perekonomian indonesia, bahkan pada masa krisis ekonomi. Secara umum pertumbuhan sektor pertanian tumbuh dengan positif, investasi PMDN untuk sektor pertanian meningkat sebesar 33 pe rsen dari tahun 2014 ke tahun 2018 atau tumbuh rata-rata sekitar 17,8 persen per tahun selama kurun waktu empat tahun. Kenyataan ini menunjukkan bahwa sektor pertanian yang di dalamnya terdapat perkebunan, memiliki arti yang sangat penting dan strategis dalam mempertahankan dan meningkatkan pembangunan ekonomi nasional. Peran penting ini ditunjukan oleh perkebunan melalui kontribusinya terhadap produk domestik bruto (PDB), ditinjau dari nilai absolut berdasarkan harga yang berlaku tahun 2014, PDB perkebunan terus meningkat sekitar Rp 37,7 triliun pada tahun 2015 menjadi sekitar Rp 57 triliun pada tahun 2018, atau dengan laju pertumbuhan sekitar 14,7 persen pertahun.

Salah satu subsektor perkebunan yang sangat berkembang adalah perkebunan karet. Selama lebih dari 35 tahun, area perkebunan karet di Indonesia meningkat sekitar 4,8\% pertahun, namun pertumbuhan yang nyata terutama terjadi pada area perkebunan karet rakyat, sedangkat pada perkebunan besar negara dan swasta sangat rendah, dibawah $1 \%$ pertahun.

Banyak usaha yang telah dilakukan pemerintah selama ini dalam pembangunan perkebunan karet seperti memberikan bibit yang berkualitas dan memberikan modal yang cukup bagi petani untuk mengelola kebun mereka.dan ada juga dengan melalui program SRDP, usaha ini dilakukan pemerintah untuk dapat meningkatkan pendapatan petani karet agar kehidupan mereka menjadi lebih baik lagi.

Kegunaan lain dari tanaman karet adalah selain dapat diambil lateksnya untuk bahan baku pembuatan aneka barang keperluan manusia, sebenarnya karet masih memiliki manfaat lain, manfaat ini walaupun sekedar sampingan,tetapi memberi keuntungan yang tidak sedikit bagi para pemilik perkebunan karet. Hasil sampingan dari tanamam karet yang memberikan keuntungan adalah kayu atau batang pohon karet tanaman tua yang ditebang dapat dimanfaatkan batangnya atau diambil kayunya

Kecamatan Batang Cenaku Kabupaten Indragiri Hulu, telah lama menjadikan perkebunan sebagai subsektor andalan dalam pencapaian pertumbuhan 
ekonomi (Economic Growth), peningkatan kesejahteraan penduduk. Komoditi-komoditi yang dijadikan basis pada perkebunan di Kecamatan Batang Cenaku adalah karet, kelapa,kelapa sawit, pinang dan lainnya.

Sebagai salah satu sektor unggulan, keberadaan perkebunan karet diharapkan mampu mewujudkan pengembangan wilayah Kecamatan Batang Cenaku. Hal ini dapat terwujud melalui efek berantai, yang pada gilirannya mampu mengembangkan sektorsektor lain baik melalui terciptanya pembangunan infrastruktur maupun sarana dan prasarana umum lain yang mampu memperlancar kegiatan perekonomian dan kehidupan masyarakat.

Dari latar belakang di atas dapat dirumuskan masalah sebagai berikut: (1) Bagaimana tingkat perbandingan pendapatan petani karet yang menggunakan bibit unggul dengan luas lahan 1 ha dan yang menggunakan bibit tradisional dengan luas lahan 2 ha terhadap peningkatan pendapatan masyarakat di Kecamatan Batang Cenaku Kabupaten Indragiri Hulu? (2) Apakah usaha pembangunan perkebunan karet rakyat yang telah dilakukan pemerintah selama ini mampu meningkatkan pendapatan masyarakat di Kecamatan Batang Cenaku Kabupaten Indragiri Hulu? Tujuan penelitian ini (1) Untuk mengetahui tingkat perbandingan pendapatan petani karet yang menggunakan bibit unggul dengan luas lahan 1 ha dan yang menggunakan bibit tradisional dengan luas lahan 2 ha di Kecamatan Batang Cenaku Kabupaten Indragiri Hulu. (2) Untuk mengetahui usaha pembangunan perkebunan karet yang telah dilakukan pemerintah dalam meningkatkan pendapatan masyarakat di Kecamatan Batang Cenaku Kabupaten Indragir Hulu.

\section{KAJIAN PUSTAKA Perkebunan}

Perkebunan di Indonesia sangatlah menjanjikan keuntungan yang besar apabila dikelola dengan baik, bahkan akan menghasilkan sumber pendapatan Negara yang dapat diandalkan untuk menunjang perekonomian Negara. Perkebunan di

Eko dan Bisnis (Riau Economics and Business Reviewe) Volume 11, Nomor 3, 27 September 2020
Indonesia menyediakan potensi yang sangat besar dan tidak ternilai apabila dikelola secara sungguh-sungguh dan dalam hal ini perlu diadakan program pendamping dan pembina secara insentif. Kualitas tanaman perkebuna Indonesia dapat ditingkatkan menjadi kualitas yang sangat baik seandainya Indonesia mampu menerapkan pengkajian dan penemuan-penemuan yang tadinya berskala penelitian di laboratorium manjadi skala usaha di lapangan. (Mangunwidjaja dan Sailah, 2005 : 105).

\section{Bibit Karet Tradisional}

Bibit karet tradisional adalah Sumber bibit biasanya berupa bibit cabutan atau biji sapuan dengan tingkat pemeliharaan yang sangat minim. Secara tradisional, pembangunan kebun karet rakyat didasari dengan pola tebang-tebasbakar yang dilanjutkan dengan pemanfaatan lahan untuk peladangan selama dua-tiga tahun pertama (penanaman tumpangsari tanaman pangan dengan tanaman karet).

Pola tanam yang dilakukan dengan menggunkaan bibit tradisional merupakan pola yang berdiri sendiri tanpa ada bantuan dari pihak pemerintah atau instansi manapun. Petani memperoleh dana dari pribadi untuk membuat lahan kosong menjadi usahatani karet yang nantinya akan menjadi mata pencaharian pokok bagi mereka. Pengembangan perkebunan dengan pola swadaya secara keseluruhan proses pembuatan kebun dilakukan dan biaya sepenuhnya oleh petani secara mandiri. Pembuatan kebun secara swadaya oleh petani karet telah dilakukan sejak lama dan turun temurun. Penyediaan lahan pada awalnya dilakukan dengan menebang hutan secara individu atau berkelompok untuk dijadikan sebagai tanah peladangan. Tanah peladangan itu kemudian ditanami pohon karet dengan menggunakan bibit tradisional. Dari waktu ke waktu luas hutan yang ditebang untuk dijadikan areal perkebunan karet rakyat selalu bertambah jumlahnya

Kendala yang dihadapi oleh sebagian besar petani karet tradisional

P.ISSN: 1410-7988 E.ISSN: 2614-123X 
adalah (1) Produktivitas karet rendah, (2) Umur karet rata-rata sudah tua dengan produktivitas rendah. (3) Kualitas bahan tanam karet yang dipakai maupun yang tersedia di tingkat petani relatif tidak memenuhi kriteria untuk dapat menghasilkan kebun karet dengan produktivitas yang baik

Masyarakat menggunakan bibit tardisional karena tidak memerlukan biaya yang besar dalam pembibitan, karena bibit bias diambil dari kebun karet itu sendiri.

\section{Pembibitan}

Para petani tradisional di Kecamatan Batang Cenaku Kabupaten Inhu rata-rata menggunakan bibit-bibit karet dari cabutan alam/liar. Cabutan liar karet tersebut berasal dari anakan karet umur kurang dari satu tahun dan dipilih yang mempunyai penampakan fisik yang bagus. Cabutan direndam dalam air mengalir atau lumpur semala 2-3 hari sampai terlihat pucuk mata tunas yang akan tumbuh. Selama perendaman tersebut, cabutan harus selalu terlindung dari panas matahari. Sebagian petani langsung dapat langsung menanam cabutan liar tersebut di lapangan tanpa merendamnya terlebih dahulu jika cuaca memungkinkan, yaitu pada saat mendung atau pada sore hari.

\section{Penanaman}

Penanaman di lapangan dilakukan pada musim penghujan, sekitar bulan Oktober sampai dengan Maret atau setelah tanah hasil tebas dan bakar tersebut sudah mulai dingin. Hal ini ditandai dengan mulai tumbuhnya rerumputan dan atau tanaman lain pada bidang bekas pembakaran. Pembuatan lubang penanaman dilakukan dengan sederhana dengan alat tugal atau tembilang. Tugal adalah sepotong kayu yang pada bagian ujungnya diruncingkan agar memudahkan pembuatan lubang tanam. Setelah umur dua tahun tajuk karet akan cenderung melebar dan menaungi tanaman di bawahnya, sehingga pada keadaan ini tanaman semusim sudah tidak dapat ditanam lagi. Kemudian barulah petani mulai menanam tanaman lain seperti kopi, kayu

Eko dan Bisnis (Riau Economics and Business Reviewe) Volume 11, Nomor 3, 27 September 2020 manis, petai, jengkol, durian, rambuatn, dan lain-lain-nya. Penanaman tanaman-tanaman tersebut tampaknya tidak diatur secara khusus, bahkan terkesan asal saja ditanam di sela-sela tanaman karet. Asal bibit tanaman tersebut umumnya dari biji.

$$
\text { Menurut Setyamidjaja }
$$
penyulaman paling tepat adalah pada saat masih ada hujan, atau pada saat musim tanam berikutnya. Pada tanaman yang belum menghasilkan, bila umurnya telah mencapai 4-5 tahun maka penyulaman tidak dilakukan lagi.

\section{Pemeliharaan}

Pemeliharaan dilakukan dengan cara sederhana, yaitu dengan penyiangan dimana tumbuhan pengganggu (gulma) yang tumbuh liar di sekitar tanaman pokok karet dibabat dan ditebas. Peralatan yang digunakan adalah sabit dan parang. Pemeliharaan pada karet muda akan relatif lebih intensif, karena karet-karet muda tersebut rentan terhadap serangan hama babbi hutan, rusa dan simpay. Sistem Tumpangsari yang dilakukan petani pada karet muda ternyata merupakan salah satu usaha pengendalian gulma yang baik. Hal ini sesuai dengan pendapat Tjitrosoedirdjo et al., (1984) dalam Setyamidjaja (2003) yang menyebutkan bahwa salah satu cara pengendalian gulma, yaitu dengan cara kultur teknis dimana pengendalian gulma tersebut dapat dilakukan dengan cara penanaman tanaman penutup tanah dan penanaman secara tumpangsari di antara tanaman karet muda. Setelah tanaman karet umur sekitar lebih dari 2-3 tahun, kebun biasanya diberakan sampai masa penyadapan mulai dilakukan. Pada kebunkebun yang diberakan, pemeliharaannya sudah mulai jarang dilakukan. Sedangkan pada kebun-kebun karet yang sudah menghasilkan, pemeliharaan mulai dilakukan kembali.

Penyiangan dan penebasan tanaman pengganggu pada tanaman karet yang sudah menghasilkan dapat dilakukan dengan penyiangan bersih atau menyeluruh (clean weeding) pada lantai kebun ataupun dengan

P.ISSN: 1410-7988 E.ISSN: 2614-123X 
penyiangan hanya di keliling batang pokok karet (circle weeding). Dari hasil wawancara penyiangan bersih dilakukan agar setelah lantai kebun bersih, anakan-anakan karet yang berasal dari jatuhan biji dalam kebun tersebut dapat tumbuh dengan baik. Anakananakan karet yang tumbuh baik akan dipelihara untuk menambah jumlah karet yang akan disadap.

Penggunaan pupuk pada kegiatan pemeliharaan kebun Karet tradisional ini jarang dilakukan. Hal ini karena selain mahalnya harga pupuk yang ada, juga karena pengetahuan para petani yang kurang dalam hal pemupukan ini. Jenis pupuk yang digunakan responden tersebut adalah pupuk kandang, Urea dan TSP. Pemupukan dilakukan terutama pada kebun karet unggul mereka, yaitu pada tiap 3 bulan setelah penanaman karet. Pupuk-pupupk tersebut dibeli dari toko-toko pertanian di Kecamatan.

Pengendalian hama dan penyakit kurang dilakukan oleh para petani. Disamping karena tingkat pengetahuan yang kurang, juga karena terbatasnya modal yang ada. Hama yang sering menyerang kebunkebun Karet di Kecamatan Batang Cenaku (terutama pada karet muda) diantaranya adalah : babi hutan (Sus scrofa), rusa (Cervis unicolor), berbagai jenis kera (Presbytis sp) dan rayap atau anaianai (Coptotermes curvignatus). Babi hutan dapat merusak karet dengan jalan memakan biji-biji di persemaian, merusak perakaran tanaman muda dan merusak kulit batang tanaman tua. Sedangkan berbagai jenis kera dan rusa sering menimbulkan kerusakan pada rantingranting dan pucuk-pucuk tanaman karet muda. Usaha yang dilakukan petani dalam pengendalian hama ini diantaranya adalah dengan pembuatan pagar keliling dan pemasangan perangkap atau jerat.

Sedangkan jenis penyakit yang sering dijumpai pada kebun-kebun Karet diantaranya adalah cendawan akar putih (Rigidoporus lignosus) dan jamur upas (Cortcium samonicolor). Ciri-ciri tanaman karet yang terserang penyakit ini antara lain adalah layunya daun-daun karet dan busuknya batang serta perakaran karet

Eko dan Bisnis (Riau Economics and Business Reviewe) Volume 11, Nomor 3, 27 September 2020
(Setyamidjaja, 2003). Pemberantasan yang dapat dilakukan oleh petani di Sepunggur hanyalah dengan menumbangkan pohon yang terserang penyakit dan membuang batang-batang tersebut agar tidak menjalar ke pohon lainnya.

Pada karet tua yang masih dipertahankan, petani biasanya melakukan sisipan. Sisipan adalah kegiatan pemeliharaan yang dilakukan dengan cara menanam bibit karet muda pada tegakan karet tua dan muda dengan tujuan untuk mengganti pohon karet yang tua atau mati maupun untuk memperbanyak jumlah batang yang kelak akan disadap. Sisipan umumnya dilakukan oleh petani karet yang mempunyai luas kebun karet yang dibawah $2 \mathrm{Ha}$ dan pendapatan rumah tangganya hanya tergantung dari produksi getah karet di kebun tersebut. Sistem ini mengacu pada sistem PRAS (Permanen Rubber Agroforestry System) yaitu sistem pengelolaan kebun Karet dengan tanpa melakukan pembukaan lahan dan hanya melakukan sisipan pada karet-karet tua sehingga terbentuk tanaman karet dengan berbagai umur untuk kelangsungan produksi getah karet yang disadap.

Tanaman sisipan diambil dari anakan karet umur 8-12 bulan. Sisipan dilakukan pada ruang-ruang kosong bekas pohon karet yang tumbang atau mati dengan jarak minimal sekitar 3 meter dari pohonpohon karet di sekitarnya. Banyaknya tanaman sisipan yang ditanam tergantung dari ruang kosong yang ada dan berapa banyaknya pohon karet yang telah tumbang atau mati. Setelah ditanam, tanaman sisipan diberi ajir untuk melindungi dari serangan hama babi hutan, rusa dan simpay. Kemudian agar tanaman sisipan cepat tumbuh maka cabang-cabang atau rantingranting pohon karet yang menaungi dipangkas sehingga cahaya matahari dapat masuk melalui celah-celah pohon karet tersebut. Untuk pemeliharaannya, di sekeliling tanaman sisipan harus sering dibersihkan dengan cara penyiangan terhadap semak belukar untuk mengurangi persaingan.

P.ISSN: 1410-7988 E.ISSN: 2614-123X 


\section{Bibit Karet Unggul}

Bibit karet unggul adalah bibit unggul memeliki sifat-sifat yang lebih baik diantaranya pertumbuhan cepat, resisten terhadap penyakit, penghasil lateks tinggi, dan sesuai dengan permintaan pasar. Masyarakat menggunakan bibit unggul karena bbibit unggul penghasil lateks tinggi di bandingkan dengan karet yang menggunakan bibit teradisional.

Tanaman karet dikatakan unggul bila potensi produksinya tinggi, tahan penyakit, dan pembudidayaannya mudah. Dalam hal ini tanaman karet merupakan tanaman klonal dengan sifat genetik yang sama karena diperbanyak dengan cara vegetatif. Perkebunan karet memang dapat dibentuk dari bibit asal biji, tetapi produksinya hanya berkisar $60 \%$ dari produksi tanaman klonal.

Kalau tujuannya untuk mempercepat pertumbuhan, tidak perlu menggunakan biji/batang lebih dari satu. Pada saat ini telah banyak klon-klon yang dikembangkan oleh Pusat Penelitian Karet yang mempunyai pertumbuhan cepat (matang sadap 39 bulan) dengan produksi tinggi. Klon-klon tersebut dikelompokkan dalam Klon Penghasil Lateks-Kayu, seperti RRIC 100, IRR 5, IRR 39, IRR 42, dan IRR 119.

Sementara itu kalau tujuan untuk mendapatkan daya hasil tinggi, dengan penggunaan biji/batang bawah lebih dari satu belum tentu dapat meningkatkan potensi klon batang atas, bahkan bisa terjadi hal sebaliknya yaitu menurunkan produksi akibat tidak terjadi kesesuaian (INCOMPATABILITY) antara klon batang atas dengan batang bawah. Beberapa klon yang mempunyai potensi produksi tinggi, yaitu BPM 24, $\mathrm{PB}$ 260, PB 330, PB 340, IRR 104, IRR 112, IRR 118, dan IRR 220, telah tersedia dan dapat digunakan untuk tujuan tersebut.

Untuk memperkuat daya saing karet yang menggunakan bibi tunggul dan bibit tradisional di pasar internasional, perlu di lakukan langkah-langkah peningkatan efektivitas dan efisiensi di semua bidang. Peningkatan yang di maksud terutama dilakukan padaproduktivitas, mutu, pemanfaatan sumberdaya, serta peningkatan aktivitas dan efektivitas pemasaran.

Upaya peningkatan harga karet ketingkat yang lebih wajar sangat di butuhkan untuk kelangsungan usaha. Dengan harga rendah dan biaya produksi yang terus meningkatakan menyebabkan banyak pengusaha yang mengalami kerugian. Sasaran utama pembangunan perkebunan adalah meningkatkan taraf hidup masyarakat secara keseluruhan dan berkesenambungan dengan menerapkan sistem usaha terpadu. Perkebunan terhadap aspek kehidupan dan kesempatan kerja dapat menggambarkan keberhasilan pengembangan perkebunan di bidang sosial ekonomi masyarakat pedesaan khususnya yang dikembangkan swasta dalam bentuk perkebunan. Meningkatnya jumlah penduduk di sektor perkebunan tersebut akan mendorong pertumbuhan berbagai bentuk kegiatan ekonomi, dalam arti positif pertumbuhan penduduk (populasi) merupakan pendorong meningkatkan kegiatan ekonomi (Todaro, 2002:261).

Karet merupakan salah satu komoditi pertanian yang penting, baik untuk lingkup internasional maupun nasional khususnya bagi indonesia. Di indonesia karet merupakan salah satu hasil pertanian terkemuka karena banyak menunjang perekonomian Negara (Karyudi dan Lukman, 2003).

Hasil sampingan lain dari tanaman karet yang memberikan keuntungan adalah kayu atau batang pohon karet. Biasanya tanaman karet yang tua perlu diremajakan dan diganti dengan tanaman muda yang masih segar dan berasal dari klon yang lebih produktif. Tanaman tua yang ditebang dapat dimanfaatkan batangnya atau diambil kayunya (Setiawan, dan Agus, 2007: 4748).

\section{Pembibitan}

Pengadaan biji untuk batang bawah (1) Benih untuk batang bawah berasal dari klon-klon anjuran untuk batang bawah seperti: GT 1, PR 300, PR 228, AVROS 2037 dan LCB 1320. Biji diambil dari areal

$$
\text { P.ISSN: 1410-7988 E.ISSN: 2614-123X }
$$


kebun yang berumur lebih dari 10 tahun. (2) Kebun biji harus bebas dari gulma, pembersihannya dapat dilakukan dengan cara kimiawi atau manual satu bulan sebelum biji berjatuhan. (3) Dua hari sebelum pengambilan biji, harus dilakukan pembersihan biji yang ada di areal kebun. Rotasi pengumpulan biji pada satu areal paling lambat 2 hari sekali. (4) Pengujian kesegaran biji secara acak, yaitu diambil 100 butir biji karet dari satu karung goni, kemudian dipecah dengan palu atau batu untuk dinilai kesegarannya. Apabila belahan biji karet masih putih murni sampai kekuning-kuningan dinilai baik, apabila berwarna kekuning-kuningan berminyak, kuning kecoklatan sampai hitam atau keriput dinilai jelek. Nilai kesegaran yang baik antara $70-90 \%$.

\section{Pemeliharaan Tanaman}

Pemeliharaan tanaman dilakukan untuk menciptakan kondisi tanaman menjadi baik sehingga tanaman tersebut dapat tumbuh, berkembang dan menghasilkan dengan baik.Bagaimana memelihara tanaman yang baik? Ada beberapa langkah yang diperlukan, yaitu (1) Menjaga kegemburan tanah, agar akar dapat tumbuh dan berkembang dengan baik. (2) Menjaga kelembaban tanah, agar unsur hara yang ada di dalam tanah bisa diserap oleh tanaman. (3) Meningkatkan kesuburan tanah, agar tanaman bisa menyerap hara tanah seoptimal mungkin. (4) Mengurangi persaingan dengan tumbuhan lain, baik dalam pengambilan air, unsur hara, cahaya matahari maupun udara. (5). Mencegah terjadinya serangan hama dan penyakit tanaman yang bisa merusak tanaman yang diusahakan.

$$
\text { Langkah-langkah pemeliharaan }
$$

meliputi aktivitas sebagai berikut: 1) Penyiangan, 2) Penggemburan tanah, dan pencegahan erosi, 3) Pemupukan, dan 4) Pengendalian hama penyakit tanaman. Sebelum melakukan pemeliharaan, sebaiknya mengetahui kondisi tanaman karet di lapangan.

Eko dan Bisnis (Riau Economics and Business Reviewe) Volume 11, Nomor 3, 27 September 2020
Tanaman karet dalam pertumbuhannnya terdiri dari dua fase, yaitu: (1) Fase umur < 3 tahun, dan (2) Fase umur $>3$ tahun

\section{Pemupukan}

Pemupukan dilakukan dua kali setahun yaitu pada semester I (Maret April) dan semester II (Oktober Nopember). Pemupukan dilakukan dengan cara dibenam, sebelum dipupuk lahan sudah harus dalam keadaan siap dipupuk (dilubang dan bebas gulma).

\section{Pendapatan}

Menurut Winardi (2005:87) pendapatan atau penghasilan adalah hasil berupa uang atau hasil berupa materi lain yang dicapai dari pengunaan kekayaan atau jasa-jasa manusia. Adapun faktor-faktor yang mempengaruhi perbedaan tingkat pendapatan yang diterima antara lain (1) Tingkat pendidikan, (2) Pengalaman kerja (2). Keahlian yang dimiliki, (3). Sektor usaha (4). Jenis usaha dan lokasi.

Pendapatan dari suatu kegiatan ekonomi dapat didefenisikan sebagai suatu pendapatan yang merupakan balas jasa dari faktor-faktor produksi yang diterima oleh setiap anggota rumah tangga atau individu yang antara lain dapat berupa : Upah/gaji dari faktor produksi tenaga kerja, sewa dari faktor produksi tanah, bunga dari faktor produksi modal. Selanjutnya menurut Winardi pendapatan rumah tangga dapat didefinisikan sebagai jumlah pendapatan riil dari seluruh pendapatan rumah tangga (pokok dan sampingan) yang disumbangkan untuk memenuhi kebutuhan bersama maupun kebutuhan perorangan dalam rumah tangga.

Pendapatan pokok yaitu pendapatan yang diterima setiap hari atau bulananlebih besar dari pendapatan sampingan, sedangkan pendapatan yang diperoleh guna menambah kekurangan kebutuhan seharihari dan biasanya berjumlah lebih kecil dari pendapatn pokok (Winardi, 1992:52). Sedangkan Mubiarto, mendefinisikan pendapatan dengan jumlah hasil penghasilan riil dari keseluruhan kegiatan

\footnotetext{
P.ISSN: 1410-7988 E.ISSN: 2614-123X
} 
ekonomi yang dilakukan. Pendapatan rumah tangga menurut Mubiarto dapat dirineikan sebagai berikut (1) Pendapatan berupa uang (2). Pendapatan berupa barang.

Pendapatan yang diperoleh untuk setiap individu biasanya terdapat perbedaan. Keadaan seperti ini wajar terjadi karena setiap individu memiliki perdedaan keahlian dibidang masing-masing. hal ini disebabkan oleh (1) Faktor Usia (2) Karakteristik bawaan sejak lahir (3) Keberanian mengambil resiko.

Pembangunan wilayah haruslah bersangkut paut dengan peningkatan pendapatan masyarakat di wilayah tersebut, yaitu yang dimaksud adalah pendapatan ratarata (income per capita) masyarakat. Pendapatan masyarakat setempat hanyalah yang bersifat nilai tambah dari kegiatan produksi tersebut (Tarigan, 2005:13). Jumlah produksi dianggap mempunyai hubungan yang positif terhadap jumlah kapital dan tenaga kerja. Hukum pertambahan hasil yang berkurang juga berlaku di sini yaitu tambahan tenaga kerja secara terus-menerus dengan jumlah kapital tertentu akan meningkatkan produksi nasional yang semakin menurun (Suparmoko, 2000:190191).

Nilai tambah menggambarkan tingkat kemampuan menghasilkan pendapatan di suatu wilayah. Pada umumnya yang termasuk dalam nilai tambah dalam suatu kegiatan produksi/jasa adalah berupa upah/gaji, laba, sewa tanah, dan bunga uang yang dibayarkan (berupa bagian dari biaya), penyusutan dan pajak tidak langsung (neto).

Tadaro (2002:60) memberikan perbedaan antara pendapatan uang (money income) dan pendapatan nyata atau riil (real income). Yang dimaksud dengan pendapatan uang adalah keseluruhan jumlah mata uang yang diperoleh seseorang pada setiap bulan. Sedangkan pendapatan nyata atau riil adalah kuantitas barang fisik dan jasa yang dapat dibelinya dengan pendapatannya uangnya itu.

Menurut teori Foland dalam Todaro (2005:82) sejumlah produksi pertanian juga berasal dari unit pertanian keluarga (family farms) dan unit pertanian skala menengah atau "keluarga besar" (multifamily farms).

Eko dan Bisnis (Riau Economics and Business Reviewe) Volume 11, Nomor 3, 27 September 2020
Unit pertanian keluarga dapat menampung 2 sampai 4 orang pekerja,sementara itu unit pertanian keluarga besar dapat menampung 4 sampai 12 orang pekerja. Unit-unit pertanian ini mampu menyeimbangkan penggunaan tenaga kerja dan luas lahan. Bahkan berdasarkan penelitian ini memiliki produktifitas yang lebih tinggi dibandingkan pertanian skala besar.

Sumantry (2010) membahas tentang perkebunan karet dalam perekonomian nasional, yang menghasilkan kesimpula. Karet memiliki peranan penting bagi Indonesia. antara lain (1) Sumber pendapatan penduduk (2) Sumber devisa negara dari ekspor nan-migas Mendorong tumbyhnya agro-industri di sektor perkebunan (4) Sumber daya hayati dan pelestarian lingkungan.

Fahrudin (2009) membahas tentang relasi dalam perkebunan karet rakyat, dengan kesimpulan:Sekitar 70 persen masyarakat yang ada di Propinsi Jambi menggantungkan hidupnya pada pengelolaan perkebunan karet, untuk melakukan pengelolaan perkebunan karet masyarakat membutuhkan tenaga kerja yang memenuhi kualifikasi untuk melakukan pekerjaan tersebut.

Sektor perkebunan karet menjadi tumpuan dan harapan banyak pihak karena diyakini telah terbukti mampu menaikan taraf hidup mereka. Hal ini terbukti dengan terus meningkatnya jumlah tenaga kerja yang bekerja di sektor ini dari tahun ke tahun. Hingga saat ini, jumlah pekerja yang bekerja sebagai penyadap karet mencapai angka ribuan orang yang mengadu nasib di berbagi lokasi perkebunan karet. Berpikir memecahkan masalah dan menghasilkan sesuatu yang baru adalah kegiatan yang kompleks dan berhubungan erat satu dengan yang lain. Suatu masalah umumnya tidak dapat dipecahkan tanpa berpikir, dan banyak masalah memerlukan pemecahan yang baru bagi orang-orang atau kelompok. Sebaliknya, menghasilkan sesuatu (bendabenda, gagasan-gagasan) yang baru bagi seseorang, menciptakan sesuatu, itu mencakup problem solving. Ini berarti

P.ISSN: 1410-7988 E.ISSN: 2614-123X 
informasi fakta dan konsep-konsep itu tidak penting. Seperti telah kita ketahui, penguasaan informasi itu perlu untuk memperoleh konsep; keduanya itu harus diingat dan dipertimbangkan dalam problem solving dan perbuatan kreatif. Begitu pula perkembangan intelektual sangat penting dalam problem solving (Slameto, 1990 dalam Iskandar, 2017).

\section{METODE}

Penelitian ini dilakukan di Kecamatan Batang Cenaku Kabupaten Indragiri Hulu. Hal ini dikarenakan Kecamatan Batang Cenaku merupakan daerah yang menjadikan komoditi karet sebagai salah satu komoditi unggulan dan dalam memenuhi kebutuhan mereka.

Populasi adalah keseluruhan dari objek penelitian yang diteliti. Populasi sebagai kumpulan atau agregasi dari seluruh elemen-elemen atau individu yang merupakan sumber informasi dalam suatu penelitian (Hadi, 2006:45). Adapun populasi dalam penelitian ini adalah seluruh petani yang memiliki perkebunan karet rakyat di Kecamatan Batang Cenaku Kabupaten Indragiri Hulu baik perkebunan karet bibit unggul maupun perkebunan karet bibit tradisional yang tercatat pada tahun 2013 yaitu berjumlah 4.319 orang.

Penarikan sampel yang ditempuh dengan mendasarkan pada judgemental atas dasar strategi kecakapan atau pertimbangan pribadi semata. Jumlah sampel ditentukan dengan menggunakan rumus Slovin (Husein, 2003:78) yaitu:

$\mathrm{n}=\frac{\mathrm{N}}{1+\mathrm{N}_{\mathrm{e}}{ }^{2}}$

Dimana :

$\mathrm{N}=$ Ukuran Populasi

$\mathrm{N}=$ Ukuran Sampel

$\mathrm{e}=$ Persen kelonggaran ketelitian karena kesalahan pengambilan sampel masih di tolerir. Maka jumlah sampel adalah:

$$
\begin{aligned}
\mathrm{n} & =\frac{4.319}{1+4.319(10 \%)^{2}} \\
\mathrm{n} & =\frac{4.319}{44.19} \\
\mathrm{n} & =97.737045
\end{aligned}
$$

Eko dan Bisnis (Riau Economics and Business Reviewe) Volume 11, Nomor 3, 27 September 2020 $\mathrm{n}=98$ orang

Jumlah sampel ini kemudian didistribusikan ke tiga desa dengan perkebunan karet terluas yaitu Desa Batu Papan sebanyak 38 orang, Desa Puntianai sebanyak 30 orang dan Desa Alim sebanyak 30 orang. Dari 98 orang petani karet di tiga desa dibagi menjadi dua bagian yaitu 49 orang petani yang menggunakan bibit unggul dan 49 orang petani yang menggunakan bibit tradisional. Dalam penelitian ini penulis menggunakan data primer dan data sekunder. (1) Observasi, merupakan salah satu tekhnik operasional pengumpulan data melalui proses pencatatan secara cermat dan sistematis terhadap objek yang diamati secara langsung. (2) Wawancara, yaitu tekhnik pengumpulan data dengan bertanya atau interaksi atau komunikasi langsung antara peneliti dan para responden sehingga dapat lebih luas dan relatif mudah untuk memperoleh keterangan-keterangan yang dibutuhkan.

Analisis data yang digunakan dalam penelitian ini adalah analisis deskriptif yaitu Analisis yang digunakan untuk memberi gambaran dan menguraikan masalah secara umum tentang suatu peristiwa yang terjadi.

\section{HASIL}

\section{Luas Lahan}

Kepemilikan Lahan Perorangan Yang Menggunakan Bibit Unggul.

Perkebunan karet bagi sebagian besar masyarakat Kecamatan Batang Cenaku merupakan sumber utama ekonomi keluarga dan penghasilan rumah tangga. Salah satu faktor yang mempengaruhi besar kecilnya pendapatan yang diterima petani karet adalah luas lahan perkebunan yang dimiliki atau dikelola. Semakin luas lahan yang dikelola maka pendapatan petani cenderung akan meningkat, asumsi ini berlaku jika faktor-faktor yang lain juga ikut ditambah. Pada Kecamatan Batang Cenaku mayoritas kepemilikan atas tanah usaha tani karet adalah 1-2 ha.

Hasil menunjukkan bahwa rekap ratarata kepemilikan lahan perorangan yang

\footnotetext{
P.ISSN: 1410-7988 E.ISSN: 2614-123X
} 
menggunakan bibit unggul di tiga Desa yang menjadi objek penelitian. Dari hasil penelitian diperoleh total kepemilikan lahan yang dimiliki oleh masyarakat berkisar antara 1 - 4 ha. Dari luas lahan secara keseluruhan yang dimiliki masyarakat belum secara keseluruhan merupakan tanaman menghasilkan, hanya berkisar antara $1-2$ ha saja lahan masyarakat petani karet yang menggunakan bibit unggul memiliki lahan yang termasuk tanaman menghasilkan. Jadi rata-rata kepemilikan lahan petani karet yang menggunakan bibit unggul dalam penelitian ini adalah petani karet yang memiliki lahan dengan tanaman menghasilkan yaitu sebanyak 1 ha.

\section{Luas Kepemilikan Lahan Perorangan Yang Menggunakan Bibit Tradisioal}

Hasil menunjukkan bahwa rekap ratarata kepemilikan lahan perorangan yang menggunakan bibit unggul di tiga Desa yang menjadi objek penelitian. Dari hasil penelitian diperoleh total kepemilikan lahan yang dimiliki oleh masyarakat berkisar antara $1-6$ ha. Dari luas lahan secara keseluruhan yang dimiliki masyarakat belum secara keseluruhan merupakan tanaman menghasilkan, hanya berkisar antara $1-2$ ha saja lahan masyarakat petani karet yang menggunakan bibit tradisional memiliki lahan yang termasuk tanaman menghasilkan. Jadi rata-rata kepemilikan lahan petani karet yang menggunakan bibit unggul dalam penelitian ini adalah petani karet yang memiliki lahan dengan tanaman menghasilkan yaitu sebanyak 2 ha.

\section{Produksi}

Pertumbuhan dan produksi karet dipengaruhi oleh banyak faktor, baik faktor luar maupun dari tanaman karet itu sendiri. Faktor-faktor tersebut pada dasarnya dapat dibedakan menjadi faktor lingkungan, genetis dan faktor teknis agronomis. Faktor lingkungan meliputi iklim dan tanah.

\section{Penerimaan}

Diketahui bahwa baik pekebun yang menggunakan bibit unggul dan yang menggunakan bibit tradisional, penerimaan yang terbesar mereka peroleh dari usaha tani karet menggunakan bibit unggul, yaitu sebesar 90,33 \% untuk pekebun yang menggunakan bibit tradisional 90,25\%.

\section{Biaya Produksi}

Untuk yang belum meremajakan biaya produksi terbesar di Desa Batu Papan sebesar Rp.2.174.556,- dengan luas kebun 3,2 Ha atau Rp.679.548,-- per hektar. Biaya tersebut lebih besar dibandingkan dengan daerah lainya karena umumnya pekebun di Desa Alim sudah menggunakan asam semut sebagai pembeku lateks dan mangkok dari plastik untuk menampung lateks, yang harganya lebih mahal. Sebaliknya di daerah lain yang hanya menggunakan bahan pembeku seperti cuka para, tawas, atau pembeku lain yang tidak dianjurkan, dan mangkok untuk lateks digunakan batok kelapa yang harganya lebih murah dibandingkan asam semut dan mangkok dari plastik.

\section{Pengeluaran Rumah Tangga}

Kebutuhan hidup adalah semua biaya yang dikeluarkan petani untuk keperluan pangan, sandang, papan, pendidikan dan kesehatan selama satu tahun. Kebutuhan pangan terdiri dari banyak beras dan lauk pauk. Kebutuhan sandang adalah kebutuhan yang dikeluarkan untuk membeli pakaian dalam satu tahun. Kebutuhan papan adalah biaya yang dikeluarkan untuk perbaikan rumah, membangun rumah dan lain-lain.

\section{Aspek Ekonomi Usahatani Tanaman Karet Bibit Unggul dan Usahatani Tanaman Karet Bibit Tradisional}

Dalam menjalankan usahataninya petani sampel tanaman karet bibit unggul dan petani sampel tanaman karet bibit tradisional harus mengeluarkan sejumlah rata-rata biaya produksi agar dapat diperoleh hasil dari usahatani tersebut

\footnotetext{
P.ISSN: 1410-7988 E.ISSN: 2614-123X
} 


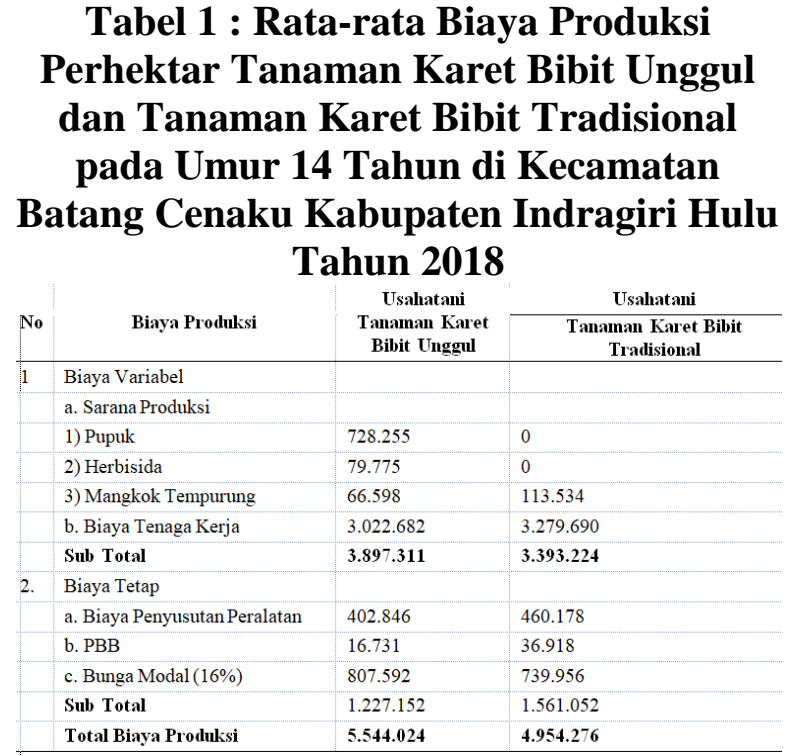

Sumber : Data Olahan, 2019

Menunjukkan bahwa usahatani petani sampel tanaman karet bibit unggul rata-rata biaya produksi per hektar per tahun lebih tinggi dibandingkan dengan rata-rata biaya produksi usahatani petani sampel tanaman karet bibit tradisional. Perbedaan ini disebabkan petani sampel tanaman karet bibit tradisional tidak melakukan pemupukan dan penyiangan sehingga tidak mengeluarkan biaya sarana produksi, biaya tenaga kerja pemupukan dan biaya tenaga kerja penyiangan. Petani sampel hanya membersihkan sebatas tempat jalan yang sering dilewati waktu menderes dan panen sehingga biaya yang dikeluarkan lebih rendah dibandingkan biaya tenaga kerja penyiangan pada tanaman karet bibit unggul.

Penelitian ini menunjukan terdapat perbedaan penggunaan biaya produksi, biaya produksi lebih banyak dikeluarkan oleh petani yang menggunakan bibit unggul. Petani yang menggunakan bibit unggu dalam penggunaan herbisida lebih banyak dibandingkan dengan petani yang menggunakan bibit tradisional penggunaan herbisida dapat meningkatkan menekan muncul hama dan penyakit yang dapat menurunkan hasil produksi. Alasan lainnya adalah, mutu karet lahan yang menggunakan bibit unggul lebih baik daripada karet yang menggunakan bibit tradisional karena ada beberapa petani yang menggunakan bibit tradisional yang tidak menggunakan bibit

Eko dan Bisnis (Riau Economics and Business Reviewe) Volume 11, Nomor 3, 27 September 2020 yang berkualitas sehingga membutuhkan perawatan yang ekstra. Sedangkan untuk penggunaan pengangkutan, penyusutan alat, dan tenaga kerja petani yang menggunakan bibit unggul lebih banyak daripada petani yang menggunakan bibit tradisional pengangkutan, penyusutan alat, dan tenaga kerja lebih kepada biaya produksi yang harus dikeluarkan.

\section{Produksi dan Nilai Produksi Usahatani Tanaman Karet}

Hal di atas menunjukkan rata-rata penerimaan per 2 hektar umur 14 tahun petani sampel tanaman karet bibit tradisional lebih tinggi dibandingkan dengan rata-rata penerimaan petani sampel tanaman karet bibit unggul dengan luas lahan 1 hektar.

\section{Analisis Pendapatan Petani Karet Yang Menggunakan Bibit Unggul Dan Bibit Tradisional Di Kecamatan Batang Cenaku Kabupaten Indragiri Hulu}

Rata-rata pendapatan petani tanaman karet bibit unggul dengan luas 1 hektar di Kecamatan Batang Cenaku Kabupaten Ingragiri Hulu dapat diketahui bahwa rata-rata pendapatan petani sampel tanaman karet bibit unggul dengan luas lahan 1 hektar lebih rendah yaitu sebesar Rp. 8.241.724 /ha/th dibandingkan pendapatan petani karet bibit tradisional dengan luas lahan 2 hektar. Ini dapat dilihat bagaimana perbandingan antara petani yang menggunakan bibit unggul dan tradisional yaitu terjadi 2 kali lipat dimana penghasilan 1 hektar bibit ungul sama dengan pendapatan 2 hektar petani yang menggunakan bibit tradisional.

Rata-rata pendapatan petani tanaman karet bibit tradisional dengan luas 2 hektar di Kecamatan Batang Cenaku Kabupaten Ingragiri Hulu dapat diketahui bahwa rata-rata pendapatan petani sampel tanaman karet bibit tradisional dengan luas lahan 2 hektar lebih tinggi yaitu sebesar Rp. 8.463.739/ha/th dibandingkan pendapatan petani karet bibit unggul dengan luas lahan 1 hektar. Ini dapat dilihat bagaimana

P.ISSN: 1410-7988 E.ISSN: 2614-123X 
perbandingan antara petani yang menggunakan bibit unggul dan tradisional yaitu terjadi 2 kali lipat dimana penghasilan 1 hektar bibit ungul sama dengan pendapatan 2 hektar petani yang menggunakan bibit tradisional.

\section{PEMBAHASAN}

Dengan demikian tanaman karet klon bibit unggul cocok menggantikan tanaman karet lokal untuk diusahakan petani. pendapatan dapat dikatakan bahwa kegiatan usahatani yang dilakukan oleh petani yang menggunakan bibit unggul lebih baik dibandingkan dengan petani yang menggunakan bibit tradisional. Hal ini disebabkan karena harga dan pendapatan bersih yang yang diterima oleh petani yang menggunkaan bibit unggul lebih besar dibandingkan petani yang menggunalan bibit tradisional dengan catatan bahwa usahatani yang dilakukan oleh kedua pola petani tersebut sama-sama memperoleh keuntungan. Rata-rata pendapatan petani sampel tanaman karet bibit unggul dengan luas lahan 1 hektar sebesar Rp. 8.241.724,-- per hektar per tahun, sedangkan rata-rata pendapatan petani sampel tanaman karet bibit tradisional dengan luas 2 hektar sebesar Rp. 8.463.739,per tahun.

Penelitian ini menunjukan terdapat perbedaan penggunaan biaya produksi, biaya produksi lebih banyak dikeluarkan oleh petani yang menggunakan bibit unggul. Petani yang menggunakan bibit unggul dalam penggunaa herbisida lebih banyak dibandingkan dengan petani yang menggunkaan bibit tradisional penggunaan herbisida dapat meningkatkan atau menekan muncul hama dan penyakit yang dapat menurunkan hasil produksi. Alasan lainnya adalah, mutu karet lahan yang menggnakan bibit unggul lebih baik daripada lahan yang menggunakan bibit tradisional karena ada beberapa petani lokal yang tidak menggunakan bibit yang berkualitas sehingga membutuhkan perawatan yang ekstra. Sedangkan untuk penggunaan pengangkutan, penyusutan alat, dan tenaga kerja petani yang menggunakan bibit unggul

Eko dan Bisnis (Riau Economics and Business Reviewe) Volume 11, Nomor 3, 27 September 2020 lebih banyak daripada petani yang menggunakan bibit tradisional seperti pengangkutan, penyusutan alat, dan tenaga kerja lebih kepada biaya produksi yang harus dikeluarkan.

\section{SIMPULAN}

Berdasarkan hasil pengkajian pada usahatani tanaman karet yang menggunakan bibit unggul dengan luas 1 hektar dan usahatani tanaman karet yang menggunkaan bibit tradisional dengan luas 2 hektar di Kecamatan Batang Cenaku Kabupaten Indragiri Hulu maka dapat diperoleh kesimpulan sebagai berikut (1) Rata-rata pendapatan petani sampel tanaman karet bibit unggul dengan luas 1 hektar sebesar Rp. 8.241.724,-- per tahun, sedangkan ratarata pendapatan petani sampel tanaman karet bibit tradisional dengan luas 2 hektar sebesar Rp. 8.463.739,- per tahun. (2) Usaha mengelola kebun karet merupakan tradisi bagi masyarakat Kecamatan Batang Cenaku Kabupaten Indragiri Hulu. Banyak usaha yang telah dilakukan pemerintah dalam pembangunan perkebunan karet, seperti dengan cara memberikan bibit yang berkualitas dan modal yang cukup bagi petani karet

\section{DAFTAR RUJUKAN}

Badan Penelitian dan Pengembangan Pertanian 2008. Prospek dan arah pengembangan Agribisnis.

Iskandar (2017). Analisis Kemampuan Problem Solving Pelajar (Kasus Pada Pelajar Pendidikan Menengah di yayasan Al-Huda Pekanbaru). Jurnal Ekodan Bisnis: Riau Economic and Busines Review, 8(4), 27-31. https://ekobis.stieriauakbar.ac.id/index.php/Ekobis/issue/vie $\underline{\mathrm{w} / 7}$

Karyudi dan Lukman 2003. Permasalahan perkebunan Karet. Pusat penelitian karet Indonesia. Jakarta.

Kurniawan, Adi. 2008. Peranan Komoditi Karet Pada Subsektor Perkebunan. Jakarta.

P.ISSN: 1410-7988 E.ISSN: 2614-123X 
Kantor Pusat Statistik Propinsi Riau, Kecamatan Batang Cenaku Kabupaten Indragiri Hulu

Muslimin N.2000. Perizinan Usaha Perkebunan. Dirjen Dephutbun. Jakarta

Mubyarto, Pengantar Ekonomi Pertanian, LP3ES, Jakarta.

Meir, GM. Baldwin, RE, Pembangunan Ekonomi, Bharatara, Jakarta.

Mosher, AT, Menggerakan dan Membangun Pertanian, CV. Yasagua, Jakarta.

Sastra Atmadja, Endang, Ekonomi Pertanian Indonesia, Penerbit Angkasa, Bandung 1999

Setyamidjaja, D., 1993. Karet Budidaya Dan Pengolahan. Kanisius, Yogyakarta.

Sianturi H. 2001. Budidaya Tanaman Karet. Medan.USU Press.

Setiawan dan Andoko A. 2005. Petunjuk Lengkap Budidaya Karet. Jakarta: PT AgroMedia Pustaka.

Setyawidjaja, D.2003. Karet budidaya dan pengelohan. Kanisisus. Yogyakarta

Sukirno, Sadono. 2004. Ekonomi Pembangunan. Lembaga Penerbit Fakultas Ekonomi UI. Jakarta

Suparmoko. 2000. Pengantar Ekonomika Makro. BPFE UGM. Yogyakarta

Tim Penulis Penebar Swadaya. 2007. Panduan Lengkap Karet. Jakarta: Penebar Swadaya

Tarigan, Robinson. 2005. Ekonomi Regional : Bumi Aksara Jakarta

http://id.wikipedia.org/wiki/Karet/17 Juli $\underline{2010}$

Winardi. 2005. Ilmu Ekonomi. Gajah Mada University Press. Yogyakarta 